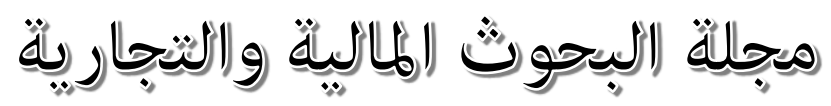

$$
\begin{aligned}
& \text { المجلد (22) - العدد الرابع -أكتوبر } 2021
\end{aligned}
$$

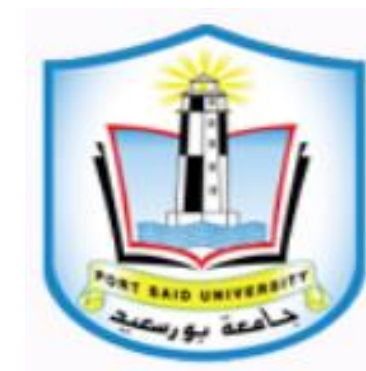

\title{
An Assessment of Customer Accounting Approach's Impact on Maximizing the Firm Value
}

\author{
Prepared by: \\ Sara Ahmed Ahmed Sharaby \\ Demonstrator in Accounting and Auditing Department \\ Faculty of Commerce \\ Port-Said University \\ Under the supervision of: \\ Prof. Dr. Fouad Mohamed El-leithy Dr. Ahmed Mohamed Wageeh \\ Professor of Accounting and Auditing Lecturer of Accounting and Auditing \\ Faculty of Commerce \\ Faculty of Commerce \\ Port-Said University \\ Port-Said University
}

https://jsst.journals.ekb.eg/ رابط المجلة 


\begin{abstract}
The Purpose of the study: the key purpose of the study is to discuss the importance and relevance of Customer Accounting to the Egyptian business environment, and to evaluate the role it plays in maximizing the value of the firm.

The Methodology of the study: the researcher conducted a questionnaire to test the hypotheses of research, the sample chosen included 95 respondents from the intended groups who benefit from customer accounting in the 30 companies in the corporate social responsibility index (S\&P) listed in the Egyptian stock of exchange, the intended groups selected are: Accountants, Financial Managers, Financial Analysts and investors.

The study results': the results of the study proved the importance of customer accounting's approach for the Egyptian business environment. As well, the evaluation of customer accounting showed that its advantages prevail over the disadvantages, which indicates that it plays a vital role in maximizing the value of the firm.
\end{abstract}

Key Words: Customer Accounting, Maximizing the value of the firm, customers as assets. 


\section{الملخص}

الهاف الرئبيسي للاراسة هو توضيح مدى أهمية و ملائمة محاسبة العملاء لبيئة الأعمال المصرية، بالاضافة الى تقييم دورها في تعظيم قيمة المنشأة.

منهبية الدراستة قام الباحث باجراء دراسة ميدانية لاختبار مدى صحة الفروض، و تتكون

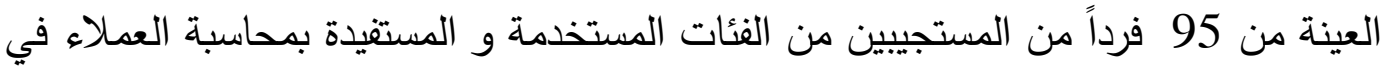

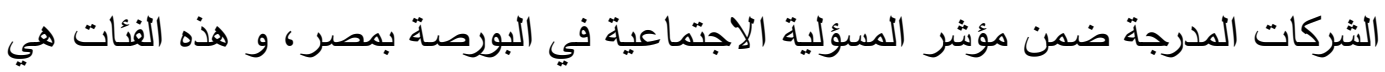
المحاسبون ، المديرون الماليون، المحللون الماليون و المستثمرون.

و اثبتت نتائج الدراسة أهية مدخل محاسبة العملاء في بيئة الأعمال المصرية ، كما أوضح تقييم المدخل أن ايجابياته قد سادت على سلبياته ، مما يدل على دوره الهام في تعظيم قيمة المنشأة. - المات الكلمات المفتاحية: محاسبة العملاء، تعظيم قيمة المنشأة، العملاء كأصول. 


\section{Chapter One: The General framework of the Study}

\section{1: The General Framework}

\subsection{1: Introduction and Problem of study:}

In the light of the rapid changes in the business environment, enterprises have become increasingly required to ensure their continuity in international markets. Enterprises must be able to complete their business domestically and internationally in order to continue in the business market. However, criticism has been directed to conventional management accounting methods, such as cost accounting systems, planning and other budgeting systems, which focus only on internal processes rather than dealing with external problems, such as: managerial competition, creating value for the customer and achieving competitive advantages.

As a result of the loss of management accounting methods to suit their relevance, business firms have increased their interest in modern methods that have the capacity to support business development and implementation of their strategic policies. These are the strategic management accounting methods that deal more with the external environment than with the internal environment. One of these methods is customer accounting that has been presented in marketing literature previously as the concept of customer relationship management (CRM).

Although there are some studies that discussed customers accounting and measuring its impact on the performance of the firm or on achieving the competitive advantage, these studies did not address the impact of the concept on maximizing the value of the firm, where the value of the firm represents (a quantitative, entire) measurement for the efficiency of management and the effectiveness of its decision in the countless aspects of the activity. Therefore, the value of the firm is considered the main element of the economic strength of the firm.

In many of the previous studies, the value of an entity has been expressed by market value, which is determined by multiplying the number of outstanding shares by the current market price per share, considering number of outstanding shares to be constant, the value of the firm is largely impacted by its market price. In order to boost the firm's value, important question how to determine the most important elements impacting its market price such as: net sales, profits, fixed assets and capital structure. 
As a result of the emphasis of the approach of customers accounting on the sales and profits that the customer contributes to the firm both in the past or future periods, and that those profits are the most important factors that affect the market value of the firm and thus in maximizing its value, the researcher seeks to evaluate the role of customer accounting approach in maximizing the value of the firm.

The research problem can be summarized by these questions:

1- What is customer accounting, what is its importance, and how relevant is it to the Egyptian business environment?

2- What is the impact of customer accounting in maximizing the value of the firm in the Egyptian business environment?

\subsection{2: Research importance and purpose:}

The scientific importance of research comes from the deficiency of accounting literature in discussing customers' accounting and the research is an extension for these studies, its purpose is to discuss the importance and relevance of Customer Accounting to the Egyptian business environment, and to assess its impact on maximizing the value of the firm.

\subsection{3: Research Hypotheses:}

The First Hypothesis is divided into:

$\mathrm{HO}_{1}$ : There are no statistically significant differences on the importance of customer accounting for the Egyptian business environment.

$\mathrm{HA}_{1}$ : There are statistically significant differences on the importance of customer accounting for the Egyptian business environment.

The Second Hypothesis is divided into:

$\mathrm{HO}_{2}$ : There is no positive impact for customer accounting on the value of the firm in the Egyptian business environment.

$\mathrm{HA}_{2}$ : There is positive impact for customer accounting on the value of the firm in the Egyptian business environment.

\subsection{4: Research Methodology:}

To achieve the study purpose both inductive and deductive approaches are used

to review the previous theoretic and practical studies, and show the results. 


\subsection{5: Research outline:}

Chapter One: The General Framework of the Research and Literature Review.

Chapter Two: The Approach of Customer accounting, A Conceptual Framework.

Chapter Three: The Impact of Customer Accounting on Maximizing the Value of the Firm.

Chapter Four: The Empirical Study.

Summary, Conclusion, and Recommendation.

\section{2: Literature Review}

\subsection{1: McManus, (2013)}

This study aimed to discuss the use of customer accounting and marketing performance measures in the Australian hotel industry. The study found that highly market-focused hotels use more customer focused accounting and marketing practices. The study recommended hotels that face huge competition to concern more for creating value to customers.

\subsection{2: Nawar, (2017)}

This study aimed to clarify the relationship between the approach of customers accounting as one of the methods of strategic management accounting and the strategic performance of business enterprises measured by the Balanced Scorecard, it also aimed to identify the determinants that give an indication of the application of customers accounting's approach. The study found that there is no significant relationship between the set of contingent variables and the approach of customers accounting. The study also found a significant relationship between the approach of customers accounting and the strategic performance of business enterprises measured by the Balanced Scorecard. 


\section{Chapter 2: The Approach of Customer accounting (CA), A Conceptual Framework.}

\section{Introduction:}

Strategically oriented Management accounting aids managers to make better decisions through providing them with financial and non- financial information, and to truly determine the firm's competitive position through focusing on customers and competitors. As a result, firms paid more attention to its customers and to the degree of their contribution to its profitability through determining revenues and costs related to them.

\section{1: The Nature of CA}

\subsection{1: CA from the perspective of Strategic Management Accounting (SMA):}

Unlike other methods of management accounting that focus on cost reduction, management and control, performance evaluation and product management, SMA focuses strongly on strategic positioning. It encompasses all information related to customers, competitors and the market, which gives the firm the ability to achieve competitive advantage and boost its market share. strategic management accounting is defined as "the provision and analysis of management accounting data about a business and its competition for the use in developing and monitoring the business strategy".

\subsection{2: The Importance of $\mathrm{CA}$ :}

Customer accounting helps to alter unprofitable customers into profitable ones and to preserve them by providing products and services with the lowest cost and the highest quality, which, in turn, surges customer's value, it also helps to determine the relationship between prices and service costs provided to the customer which allows the firm to impose a high price on services with great costs and vice versa. Moreover, Customer accounting is also useful for planning business resources, as it aids in allocating promotion expenses, marketing mix and others, this function is related to grading customers by their profitability that can result in utilizing resources in a better way. 


\subsection{3: Barriers to the Application of CA:}

Problems of information technology is one of the main barriers because firms may lack integrated computer systems, as well as, the existence of other organizational priorities for the firm, would also make it difficult to adopt customer accounting. Other obstacles are: resistance of change among employees, this can be a result of the dependency of the modern systems on information more than employee's judgement, and matching the modern system with the firm's environment.

\section{2: Dimensions of CA}

\section{Introduction:}

CA dimensions are directed to create pellucidity for the revenues and costs involved in treating customer relations, which can aid in the decisions of allocating resources. Therefore, the researcher will discuss these dimensions below.

\subsection{1: Customer Profitability Analysis (CPA)}

CPA is "the process of allocating revenues and costs to customer segments or individual customer accounts, such that the profitability of those segments and / or accounts can be calculated". CPA can be done for both of individual customers or a group of customers, it encompasses a group of elements, such as: The analysis of customer revenue, The analysis of customers costs. to calculate customers profitability, expenses such as "presale, production, distribution, and post-sale service costs" should be included. These costs should be managed according to the activity that drives costs and this can be implemented by using ABC to assign SMDA costs to customers.

\subsection{2: Lifetime Customer Profitability Analysis (LCPA or CLV)}

LCPA is also called customer lifetime value (CLV) and is defined as "the present value of all future cash flows obtained from a customer over his or her life of relationship with the firm". Customer lifetime value can provide management with information about the costs of customers, revenues generated from them in the future, as well as, their future contribution to the firm's profitability. In response, researchers paid a great attention to the measurement of CLV, one example for approaches used to measure CLV is that it can be estimated with a simple assumption of constant customer's margin and constant retention rate. Another approach 
to calculate customer lifetime value is based upon the historic profit contribution of customers and forthcoming cash flow.

\subsection{3: Valuation of Customers as Assets (VCA):}

The concept is defined as "combination of both financial value which is based upon the profitability or lifetime value and relational value which might include profile, advocacy, learning and information, and new product development". In order to value customers as assets, the firm needs to estimate the direct and indirect customer's contribution to the firm's profits; the direct customers contribution is "the economic value of the customer relationship with the firm expressed as contribution margin or net profit", while the indirect one represents "customer referrals, customer impact through social media and the customer feedback". Commonly used methods for valuing intangible assets, including assets related to customers are "cost method, market method and income method".

\section{Chapter Three: The Impact of CA on Maximizing the Value of the Firm}

\section{Introduction:}

Value is the indispensable dimension of measurement in a market economy. Individuals invest in the prospect that when they trade, the value of each investment will have grown by an adequate amount above its cost to recompense them for the risk they took. Definitely, in a market economy, the firm's competence to create value for its shareholders and how much value it creates are the principal measures by which it is valued.

\subsection{The Essence of the Firm Value}

\subsection{1: What is The Firm Value?}

In response to the importance of shareholders to the firm as they exploit many resources in it, a lot of researchers agreed that the value of the firm is "the value to its shareholders", total value comprises the anticipated future cash flows yielded by the firm's assets, discounted to the nowadays using a proper rate of discount. A lot

\subsubsection{Factors affecting the value of the Firm:}

A lot of factors can affect the value of the firm; Profitability which is one of the important factors that has a great effect on firm value, firms that achieve high profitability are experiencing better resources management that generate revenue to be received in the form of dividends; corporate 
governance, studies show that by improving corporate governance

applications at the firm-level, the price of firm's stock increases, and such greater market values could imply higher total firm value; intellectual capital (IC) has a pivotal role in strengthening a firm's competitive position and in accomplishing its objectives.

\subsection{3: Valuation Methods of the Firm}

\subsubsection{1: Book Value Method:}

This method depends on the financial accounting concept that owners' equity is identified by subtracting the total liabilities of the firm from its total assets. While many specialists accepted the concept, most came to an agreement that the method has grave mistakes because most assets are recorded at historical cost subtracted from it, when proper, the accumulated depreciation or cumulative damages, which cannot reflect existing asset value.

\subsubsection{2: Adjusted book value:}

This method offers a solution for problems arising when using pure accounting standards in the firm's valuation. under this method the assets and liabilities are adjusted according to market changes in order to exclude the effects of inflation. researchers stated that despite the usefulness of this method in adjusting assets recorded in the balance sheet to the existing market values to overcome the problem of historical asset' s value, a great effort and data are needed to reach this market value.

\subsubsection{3: Economic value added (EVA)}

It is "a management tool that allows performance measurement of a firm or investor", they stated that EVA is the more suitable method to measure the firm's internal and external performance for a number of reasons, EVA helps in minimizing agency conflict, improving decision making and it is accompanied with stock return than other measures.

\subsection{The Role of CA in the Firm's Value Maximization}

\section{Introduction:}

CA dimensions play a pivotal role in helping the firm to attain the desired level of performance by concentrating on the most important source of profitability and excellence for the firm, which is customer, those practices also support the firm to achieve competitive advantage as they are 
strategically oriented. the three CA dimensions have a lot of advantages, they also have some disadvantages that should be evaluated.

\subsection{1: Evaluating the Dimensions of Customer Accounting}

CPA depends upon actual historical data rather than estimations which makes it a reliable technique, it also aids firms that have few customers to determine how they can rely on a small number of customers to gain large profits. On the other hand, managers are influenced by CPA results and decrease or even exclude un profitable customers, but this can harm the firm if the non- profitable customer afford a considerable part of fixed costs.

Customer life time is a future oriented technique, that makes firms able to calculate the customers value to the firm over their lifetime, and it allows firms to determine the monetary value of each customer. On the other hand, CLV takes direct customer contribution into consideration but does not integrate the effect of indirect contribution from other sales.

The advantages of VCA are similar to those of CLV that, it is future oriented and assessing the value of customers as assets depends on cash flows estimations, but it differs from CLV that it includes both of the direct and indirect cashflows. The disadvantages of VCA are embedded in the fact that customers differ from brands, that they are free and can decide to continue with the firm or leave it unpredictably.

\subsection{2: Solutions for Some Disadvantages of Customer Accounting's Dimensions:}

The problem of in accurate forecasts related to future dimensions can be easily solved by using well developed customer relationship management systems and forecasting techniques, examples of forecasting techniques are: Random -forest regression (RF) which can predict the customer profitability value by using only a small group of variables, Monte Carlo simulation method, Machine learning methods that do not use traditional learning methods which are imperfect. While the problem of valuing indirect customers contribution can be solved by using metrics, such as: customer referral value (CRV), the value of customer impact (CIV).

\subsection{3: The Impact of Customer Accounting on Firm Value Maximization}

Researchers revealed that firms that apply customer accounting practices can make faithful customers, retain and satisfy them. Researchers also stated that customer relationships are a very important output for customer accounting, improved customer relationships help in maximizing 
the value of the firm, and also help firms to gain more values CLV maximization leads to the long- term profit maximization and the financial well-being of the firm.

Customer accounting supports management decision making by categorizing customers into ranked groups based on profitability and possibility for growth. As well, one of the market- based capabilities that create firm value is to manage customers by building relationships with them through rich and acceptable experiences, and improving customer responses for the best revenue and profit.

\section{Chapter Four: An empirical Study}

\section{1: Introduction and purpose of the Study:}

In this chapter an empirical study is conducted to show the specialists' opinion in the Egyptian environment about all aspects which the researcher discussed in the theoretical part using a questionnaire to test the hypotheses of the study. The research has chosen a sample of 95 respondents including: Accountants, Financial Managers, Financial Analysts and Investors.

\section{2: Hypotheses Testing and Discussion of Findings}

The Results of the Empirical Study provided the Following:

1- There are no statistically significant differences on the importance of customer accounting for the Egyptian business environment.

2- There is positive impact for customer accounting on the value of the firm in the Egyptian business environment.

\section{Conclusions:}

1- $\mathrm{CA}$ is imperative and important for the Egyptian business environment.

2- CA adoption faces some challenges, such as: problems of information technology, resistance of change, lack of knowledge about the benefits of implementation, lack of training courses, as well as, lack of management support.

3- CA is affected by some variables, such as: intensity of competition, environmental uncertainty, firm size and strategy.

4- The pros of CA dimensions prevail over the cons, as the cons can be overcome by several methods.

5- CA has a pivotal role in maximizing the value of the firm. 


\section{References:}

1. Abbas, E, G., (2019), " The Role of Customer Accounting Dimensions in Supporting Sustainable Competitive Advantage in The Banking Sector", The Scientific Journal of Business and Environmental Studies, Suez Canal university, The Faculty of Commerce, Vol.10, No.3, pp:395-419.

2. Adigbole, E., O, Osemene., and O. Fakile ., (2019), "Strategic Management Accounting and Information for Managerial Decision Making in Selected Manufacturing Firms in Kwara State." Ilorin Journal of Management Sciences, pp:131-146.

3. Albalaki, F, M., R, Mageed, (2018), " Customer Profitability Analysis, Cost System Purposes and Decision -Making Process: A Research Framework", Accounting and Financial Management Journal, Vol.3, No.5, pp:1547-1552.

4. AL-Dweikat, M., M, Nour, (2018), "Balanced Scorecard Critical Success Factors of Jordanian Commercial Banks and Its Effect on Financial Performance", Accounting and Finance Research, Vol.7, No.3, pp:146-153.

5. Al-Sayed, A, M., (2019, "A Proposed Framework for Integrating Resource Consumption Accounting (RCA) and Attributes BasedCosting (ABC II) to Support Customer Profitability Management (CPM) (with a field study)", Journal of Contemporary Business Studies, Vol.7, pp:437-483.

6. Dheseviano, E., A, P, Egbunike, (2018), " Strategic Management Accounting Practices and Organizational Performance of Manufacturing Firms in Nigeria", Journal of Accounting and Financial Management, Vol.4, No.1, pp:10-18.

7. Endraria., (2015), "Strategic Management Accounting "What happened to you", European Journal of Business and Management, Vol.7, No.12, pp:222-226.

8. Fowzia, R., Afroz, F, (2016)," Strategic Management Accounting Techniques of Manufacturing Organizations of Bangladesh with Special Reference to Satisfaction Level", DIU Journal of Business and Economics, Vol.10, No.2, pp.123-134.

9. Haisleb, J, Z., V, J, Richardsons., (2017), " The effect of Customer Relationship Management systems on firm performance", International Journal of Accounting Information Systems, Vol.27, pp:16-29.

10. Helgesen, Ø., H, M, Sandanger., and J, Sandbekk., (2018), “Do customer profitability analyses pay? A survey of large Norwegian 
companies", International Journal of. Managerial and Financial Accounting, Vol. 10, No. 4, pp.352-357.

11.Hudaib, T. S., (2018), "Innovation as an element of strategic management accounting", Journal of Accounting. Analysis. Auditing, Vol.5, No.3, pp.24-29.

12. Hussein, A., (2018), "Adoption, Importance and Barriers to the Implementation of Contemporary Management Accounting Practices: Evidence from Egypt", Accounting and Finance Research, Vol.7, No.1, pp:192-213.

13. Jonah, N., I, G, Ornguga., and E, Torsen., (2016)," The Effect of Total Quality Management (TQM) on the Organizational Growth of Adama Beverages: A Marketing Mix Perspective", International Journal of Science and Research, Vol.7, No.7, pp:1096-1102.

14. Masschelein, S., (2018), "ACCT3323: Strategic Management Accounting" Available at SSRN, pp:1-84.

15.Novianty, I., (2015), "Strategic Management Accounting: Challenges in Accounting Practices", Research Journal of Finance and Accounting, Vol.6, No.9, pp:7-13.

16.Nuhu, N. A., Nuhu., K, Baird., and A, B, Appuhamilage., (2017). "The adoption and success of contemporary management accounting practices in the public sector", Asian Review of Accounting, Vol.25, No.1, p:106-126.

17. Nurliati, A., (2018), " Strategic Accounting Management Where are You Going?", Journal of Economics, commerce and management, Vol.6, No.12, pp:633-643.

18. Oyewo, B., S, Ajibolade., (2019), "Does the Use of Strategic Management Accounting Techniques Creates and Sustains Competitive Advantage? Some Empirical Evidence", Annals of Spiru Haret University, Economic Series, Vol.19, No.2, pp:61-91. 
19.Roslender, R., Hart, S, J., (2003). "In search of strategic management accounting: Theoretical and field study perspectives", Management Accounting Research, Vol.14, No.3, pp:255-279.

20. Saponja, L, D., E, Suljovic., (2017), "Strategic management accounting in the Republic of Serbia", Journal of Economic Research, Vol.31, No.1, pp:1829-1839.

21. Sedevich-Fons, L., (2018), "Linking strategic management accounting and quality management systems", Business Process Management Journal, Vol.24, No.6, pp:1302-1320.

22.Simmonds, K., (1981), "Strategic management accounting", Management Accounting Journal, Vol. 59, No. 4, pp:26-30.

23. Thapayom, A., (2019), " Customer Accounting and Competitor Accounting as a Strategic Approach for Goal Achievement: Evidence from Auto Parts Manufacturing Companies in Thailand", Modern Management Journal, Vol.17, No.1, pp:13-27.

24. Ussahawanitchakitm, p., (2017), "Customer Accounting as a Valuable Approach of Strategic Management Accounting: Evidence from Hotel Businesses in Thailand", Journal of Business Administration, Vol.40, No.154, pp:37-57. 